NBER WORKING PAPER SERIES

\title{
ESCAPE FROM THE CITY? THE ROLE OF RACE, INCOME, AND LOCAL PUBLIC GOODS IN POST-WAR SUBURBANIZATION
}

\author{
Leah Platt Boustan \\ Working Paper 13311 \\ http://www.nber.org/papers/w13311 \\ NATIONAL BUREAU OF ECONOMIC RESEARCH \\ 1050 Massachusetts Avenue \\ Cambridge, MA 02138 \\ August 2007
}

I thank Claudia Goldin, Caroline Hoxby, Lawrence Katz and Robert Margo for their advice and support. This paper has also benefited from conversations with David Abrams, Sandra Black, David Clingingsmith, William Collins, Dora Costa, Carola Frydman, Edward Glaeser, Matthew Kahn, Nora Gordon, Byron Lutz, Sarah Reber, Steven Rivkin, Raven Saks and Bruce Weinberg, and from the suggestions of participants at many conferences and seminars. Lilia Garcia, Michael Latterner, David Lee, Angelina Morris, Danika Stegeman, Mingjie Sun and Qiong Zhou provided excellent and enthusiastic research assistance. Wendy Thomas generously assisted with aspects of the data collection. I gratefully acknowledge the financial support of the Center for American Political Studies and the Taubman Center for State and Local Government, both at Harvard University, the California Center for Population Research at UCLA, and dissertation fellowships from the Economic History Association and the Rovensky Fellowship in Business and Economic History. Sections of this paper were written while visiting the Minnesota Population Center. The views expressed herein are those of the author(s) and do not necessarily reflect the views of the National Bureau of Economic Research.

NBER working papers are circulated for discussion and comment purposes. They have not been peerreviewed or been subject to the review by the NBER Board of Directors that accompanies official NBER publications.

(C) 2007 by Leah Platt Boustan. All rights reserved. Short sections of text, not to exceed two paragraphs, may be quoted without explicit permission provided that full credit, including $\mathbb{C}$ notice, is given to the source. 
Escape from the City? The Role of Race, Income, and Local Public Goods in Post-War Suburbanization Leah Platt Boustan

NBER Working Paper No. 13311

August 2007, Revised May 2013

JEL No. H71,H72,H73,N92,R21

\begin{abstract}
Affluent towns often deliver high-quality public services to their residents. I estimate the willingness to pay to live in a high-income suburb, above and beyond the demand of wealthy neighbors, by measuring changes in housing prices across city-suburban borders as the income disparity between the two municipalities changes over time. I find that a $\$ 10,000$ increase in town-level median income is associated with a seven percent increase in housing values at the border. The estimated demand for high-income municipalities is primarily driven by school quality and lower property tax rates.
\end{abstract}

Leah Platt Boustan

Department of Economics

8283 Bunche Hall

UCLA

Los Angeles, CA 90095-1477

and NBER

lboustan@econ.ucla.edu 


\section{Introduction}

Residential segregation by income has increased in the United States over the past few decades. Much of this income segregation takes place between jurisdictions, especially between central cities and suburbs (Fischer, et al., 2004). For example, in 1940, the typical suburban resident earned only three percent more than his urban counterpart. By 2000, the income gap between residents of cities and suburbs increased to 16 percent. The concentration of affluent households in high-income towns generates disparities in the quality of local public goods, including public safety and elementary and secondary schooling, between jurisdictions.

This income differentiation between central cities and suburbs coincided with a growing demand for suburban residence. From 1940 to 2000, the share of metropolitan population living in the suburbs increased from 40 percent to 68 percent. One attraction of living in a high-income town is the presence of affluent neighbors (Ioannides and Zabel, 2003; Bayer, Ferreira, McMillan, 2007). Another benefit of such towns may be the quality of public goods offered to their residents. Towns with wealthy residents often enjoy a large property tax base from which to raise revenue and a local electorate with preferences for high-quality public services. ${ }^{1}$

This paper examines the demand for residence in a high-income suburb - above and beyond the demand for affluent neighbors - by comparing the prices of adjacent housing units on either side of city-suburban borders. Because high-income towns also tend to have other attractive qualities, such as newer housing units and more open space, I narrow the comparison to neighboring Census blocks. Furthermore, I estimate panel regressions that demonstrate how the suburban housing price premium at the border responds to changes in the characteristics of

\footnotetext{
${ }^{1}$ Suburbanization was also driven by the falling time cost of commuting associated with the diffusion of the automobile and large state and federal road building programs (LeRoy and Sonstelie, 1983; Baum-Snow, 2007; Kopecky and Suen, 2010) and by rising crime rates and increasing racial diversity in central cities (Cullen and Levitt, 1998; Boustan, 2010).
} 
city and suburban residents. Adding this panel dimension allows me to control for remaining (fixed) differences in the quality of housing or neighborhoods on the suburban side of the border, for example due to municipal zoning ordinances or to the sorting of households according to their preferences for public goods.

It is important to emphasize that this research design uses housing prices at municipal borders to assess willingness to pay for average characteristics of residents throughout the jurisdiction. For example, between 1970 and 1980, the median income for residents of the town of Evanston, IL increased by $\$ 2,000$, while the median income for residents of neighboring Chicago decreased by $\$ 3,000$ (in 2000 dollars). This $\$ 5,000$ difference in jurisdiction-level median income is associated with a widening of the housing price gap at the Chicago-Evanston border by 3 percentage points. Over this period, there was no differential change in observable characteristics of the housing units or of the residents across this political boundary.

The empirical analysis focuses on the years 1960 through 1980, a peak era of suburbanization in the United States. I find that, in this period, the marginal homeowner was willing to pay 7.4 percent more for an otherwise equivalent housing unit located in a town whose median income was $\$ 10,000$ higher than that of the neighboring city, even after controlling for housing and neighborhood quality. Using a series of fiscal and expenditure variables, I then demonstrate that the demand for living in a wealthy town stems primarily from lower property tax rates set by jurisdictions with a larger tax base and higher school quality in wealthier districts (despite equal expenditures per pupil). ${ }^{2}$ Taken together, these two factors can explain half of the estimated willingness to pay to live in an affluent town.

\footnotetext{
${ }^{2}$ Lacking direct measures of school quality, such as test scores, during this period, I proxy for school quality with the share of residents holding a college degree.
} 
A novel feature of this research design is to combine cross-border variation in housing prices with changes in jurisdiction attributes over time. ${ }^{3}$ Using panel data allows for pre-existing gaps in housing or neighborhood quality across jurisdiction borders. The identifying assumption in the panel is that the direction and pace of change in housing and neighborhood quality over time is common to both sides of the border. I present three pieces of evidence consistent with this assumption. First, I find no differential trend in observable housing quality measures, such as unit size, over time. Second, the effects of jurisdiction characteristics on housing prices are equally strong in a series of subsamples which are less likely to have experienced differential changes in neighborhood composition or local land use policy. Third, housing prices do not respond to town-level median income in a placebo sample of southern cities for which jurisdiction borders are less tied to local public goods. Many of these southern cities belonged to consolidated school districts shared with their neighboring suburbs and offered limited voting rights to poor residents during this period.

The remainder of the paper is organized as follows. The next section introduces the estimation methods used to relate housing prices to a jurisdiction's median income or poverty rate. Section III describes the unique data set of Census blocks along municipal borders. In Section IV, I present the relationship between jurisdiction-level income and housing prices and test the maintained assumption that housing quality changes at the same rate across borders. Section V explores the local governmental channels that give rise to the willingness to pay for wealthy co-residents. Section VI concludes.

\footnotetext{
${ }^{3}$ Other recent work using housing values to estimate household preferences for neighborhood and community attributes include Black (1999); Kane, Staiger and Samms (2003); Barrow and Rouse (2004); Figlio and Lucas (2004); Chay and Greenstone (2005); Reback (2005); Greenstone and Gallagher (2008); Gibbons, Machin and Silva (2009) and Machin and Salvanes (2010). This literature draws on the theoretical contributions of Rosen (1974). These studies either leverage cross-border variation (e.g., Black, 1999) or exogenous changes over time in, say, school policy (e.g., Reback, 2005) but, to date, have not combined the two. Boustan (2012) is one exception.
} 


\section{Using Housing Prices to Elicit the Demand for Wealthy Co-Residents}

\section{A. An Econometric Framework}

The goal of this paper is to estimate the marginal homeowner's willingness to pay to live in a town with affluent residents, for example because such towns enjoy a larger property tax base and offer a bundle of higher-quality public goods. If the marginal homebuyer prefers to live in a high-income suburb, we would expect housing prices in such towns to be higher than those in neighboring, low-income cities. However, housing units in wealthy suburbs also differ from those in cities in a number of ways, including age of the unit, lot size, and so on. Therefore, my preferred specification limits attention to Census blocks on either side of the city-suburban border.

A cross-border comparison minimizes disparities in housing quality between housing units located in different jurisdictions. The identifying assumption behind this approach is that neighborhood and housing quality varies continuously across municipal borders, while local policy and tax rates, which are a function of the characteristics of the local electorate, shift discontinuously at the boundaries. However, the neighborhoods alongside borders that have been in place for many years may endogenously diverge as the housing stock deteriorates or as different types of households move in. I address this concern by following border areas over time, assessing whether changes in the characteristics of jurisdiction residents are associated with changes in the housing price gap at municipal borders. ${ }^{4}$

This section describes cross-section and panel estimation strategies used to elicit this willingness to pay parameter. I begin by pooling data from the 1960 to 1980 cross-sections and estimating:

\footnotetext{
${ }^{4}$ For a thorough discussion of a related econometric framework, see Turner, Haughwout and van der Klaauw (2011). This paper moves beyond their outlined framework by adding a panel dimension.
} 


$$
\ln \left(\mathrm{PRICE}_{i j b t}\right)=\beta \mathrm{INCOME}_{j t}+\Phi^{\prime}(\text { block })_{i t}+\Psi^{\prime} \mathrm{d}_{b t}+\varepsilon_{i j b t}
$$

where $i$ indexes Census blocks, $j$ jurisdictions, $b$ border areas, and $t$ Census years. A border area consists of a pair of jurisdictions, one of which is a city and the other a suburb. PRICE represents one of three block-level dependent variables: the mean value of owner-occupied units, the mean rent for rental units, and combined measure of the user cost of housing. The key explanatory variable, INCOME, is measured at the jurisdiction level as either the median income or the poverty rate of a jurisdiction's residents. Some specifications also add available block-level housing and neighborhood quality controls $\left(\right.$ block $_{i t}$ ). Regressions are weighted by the number of relevant housing units on the block and standard errors are clustered by border area.

Central to identification in the cross-section is the vector of indicator variables $\left(\mathrm{d}_{b t}\right)$, one for each border area $b$ in Census year $t$. This vector captures unobserved neighborhood characteristics that are accessible to residents on either side of a border at a point in time - for example, the presence of a nearby park, bus line, or commercial strip. These fixed effects also control for common aspects of the housing stock, such as the age and architectural style of the units. The effect of town-level income is thus identified by comparing the prices of neighboring housing units located in either the poorer or the richer municipality within a border area. A positive $\beta$ implies that houses located in a wealthier town command systematically higher prices than their cross-border neighbors.

Equation 1 is estimated using two samples of Census blocks. The first sample contains blocks that are themselves adjacent to the border on either side ("block sample"). The second sample includes blocks up to six blocks away from the border on either side ("tract sample"). 
This larger sample is intended to reflect the size of a Census tract, a geographic unit often used interchangeably with the idea of a "neighborhood."

In the cross-section, $\beta$ will be biased upward if high-income towns offer superior housing or neighborhood quality that is apparent even for blocks adjacent to the border. It is possible that housing or neighborhood quality jumps discontinuously at a municipal border due to local zoning regulations (e.g., lot size restrictions) or to household sorting in response to long-standing differences in access to public goods. ${ }^{5}$ One solution to these concerns is to examine changes in the housing price gap at municipal borders as the characteristics of the jurisdictions' residents evolve over time. Although zoning laws can themselves change over time, housing units built before the new regulation are almost always "grandfathered in"; that is, they are allowed to remain standing despite being out of compliance with the current law. ${ }^{6}$

Equation 2 exploits the panel nature of the dataset to estimate the relationship between decadal changes in housing prices and in town-level median income:

$$
\ln \left(\mathrm{PRICE}_{i j b t}\right)=\beta \mathrm{INCOME}_{j t}+\Phi^{\prime} \text { block }_{i t}+\Psi^{\prime} \mathrm{d}_{b t}+\Omega^{\prime} \mathrm{d}_{b j}+\varepsilon_{i j b t}
$$

In addition to the common border area effect $\left(\mathrm{d}_{b t}\right)$, this specification includes a distinct fixed effect for each side of a border area, expressed as an interaction between border area $b$ and jurisdiction $j\left(\mathrm{~d}_{b j}\right)$. This vector absorbs any fixed difference in housing or neighborhood quality across borders due to zoning rules or household sorting. $\beta$ is now identified from differential changes in housing prices across borders over time.

\footnotetext{
${ }^{5}$ In a cross-border comparison, the importance of housing sorting depends on the radius of interaction. If households put much more weight on their next-door neighbors than on neighbors living one block away, household sorting can be a confounding factor in this cross-border design.

${ }^{6}$ The housing stock along most of the borders in the sample was developed before 1960 and there is little evidence of new construction over the period. The number of units on the typical block is nearly identical between 1960 and 1980.
} 
Even in a panel context, there are a number of reasons why $\beta$ will not reflect the true willingness to pay for living in a high-income town. First, there are other demographic characteristics, such as the black population share in the town, that are correlated with income and could be generating the observed housing price effect. I explore this possibility below by controlling for a set of other town-level demographics. Second, changes in the income level of municipal residents could be correlated with changes in housing or neighborhood quality, even at the border. If demand for living in a particular jurisdiction increases, homeowners may respond by investing in new home renovations. I control for changes in housing characteristics over time but am limited by the limited set of attributes available in the Census. Yet unobservable changes in housing quality that occur differentially across the border may still remain and would confound the estimate of interest.

The generalizability of the cross-border estimates depends on whether residents of border areas reflect the preferences of other city and suburban residents. Suburban households living near the border chose to be closer to the city center than other suburban residents, suggesting that they place a lower value on being physically separated from the low-income city population. If suburbanites on the border also have weaker preferences for the suburban bundle of public goods, the coefficients may underestimate the true willingness to pay for living in an affluent suburb. Furthermore, some local public goods, such as parks and libraries, can be shared by nonresidents. These non-exclusive public services will not vary discontinuously at municipal borders and therefore will not contribute to the willingness to pay for living in a high-income town in this research design. As a result, this approach can again underestimate the true willingness to pay for living in an affluent suburb. 


\section{B. Predictions from Jurisdiction Choice Models}

Various models of jurisdiction choice predict that housing prices will rise with the income level of a town's residents, thereby generating a gap in housing prices at the border of rich and poor towns. The parameter estimated in this analysis cannot differentiate between these two classes of models. One set of these models begins with the observation that the rich are more willing than the poor to trade off a dollar of private consumption for a dollar of public expenditure (see, for example, Tiebout, 1956; Ellickson, 1971; Westhoff, 1977; Epple and Romer, 1991; Fernandez and Rogerson, 1996). These models generate equilibria in which individuals self-select into towns populated by others of the same income level. ${ }^{7}$ Epple and Sieg (1999) incorporate housing markets into a framework in which multiple communities fund locally-provided public goods through property taxation. ${ }^{8}$ They prove that, in this context, housing prices will be higher in rich areas and will serve as an effective means of stratification because the poor will not want to settle in rich towns at the equilibrium price. ${ }^{9}$

An alternative class of jurisdiction choice models focuses on the property tax system (Buchanan and Goetz, 1972; Hamilton, 1976). Rich towns have a larger tax base and so are able to afford an equivalent bundle of public goods at a lower tax rate. These models give rise to a "poor chasing the rich" equilibrium in which agents of all income levels prefer living in a town

\footnotetext{
${ }^{7}$ Epple and Platt (1998) consider a model in which individuals differ along two dimensions: income and preferences for public goods. In this case, sorting need not happen only along income lines but, instead, a poor household with strong preferences for public goods may select to live in a "rich" community.

${ }^{8}$ Calabrese, Epple, Romer and Sieg (2006) extend this model to consider the role of peer effects. In their framework, the quality of local public good are produced by some combination of local expenditures and higher peer quality. In this case, higher quality peers allow richer towns to achieve a given quality of public goods with a lower tax rate. I find evidence consistent with this model in Table 5, which shows that rich towns have lower property tax rates than poor towns and yet have equal per-pupil educational expenditures and higher school quality.

${ }^{9}$ Epple and Sieg (1999) assume that the housing supply is less-than-perfectly elastic. Without this assumption, the housing supply in rich towns would simply expand until housing prices equal construction costs. During this period, suburban housing supply was expanding but new construction occurred in outlying areas. Given commuting costs, outlying houses are imperfect substitutes for housing on the border. Essentially, we should think of the supply of houses at city-suburban borders as fixed during this period.
} 
with wealthier co-residents. ${ }^{10}$ The fiscal subsidy offered in rich towns will be capitalized into housing prices, again generating a price gap at town borders.

\section{Collecting Housing Prices Along Jurisdictional Borders}

My empirical strategy combines block-level data on housing values from the US Census of Housing with municipality-level information on socio-economic status and local public goods from the Censuses of Population and Governments. Detailed data on local government expenditures and property tax rates are only available for jurisdictions with 10,000 residents or more. For the subset of towns of this size, I use tract- and block-level Census maps to identify city-suburban borders along which block-level data is reported on both sides. I exclude borders that are entirely obstructed by features like a railroad track, a body of water or a large tract of industrial land. ${ }^{11}$

Ruling out obstructed borders improves the plausibility of the identifying assumption. However, it also raises the question of endogenous border formation. Municipalities can erect bulwarks against unwanted populations by zoning for industrial use along their borders or constructing large roadways with limited ability for pedestrian crossing. Cicero, IL is (in)famous for its ethnic and racial exclusivity (Keating, 1988). It may be no coincidence, then, that the Chicago/Cicero border is obstructed by industrial land. As a result, border selection will favor

\footnotetext{
${ }^{10}$ Henderson (1985), Wheaton (1993) and others point out that zoning regulations can prevent the poor from successfully chasing the rich.

${ }^{11}$ The fitness of each border is determined by examining Census block maps. In particular, I subdivide border areas into series of tract pairs consisting of one tract on either side of the border. A border is only excluded if all tract pairs along the border are obstructed in some way. I recorded the reason for each pair's exclusion in a border selection dataset that is available upon request. Reasons for pair exclusions include features like cemeteries, golf courses, ponds, park land and highways. This search for borders along which the identification assumption is more likely to hold is similar to Turner, Haughwout and van der Klaauw's (2011) focus on "straight" borders that were created by land survey, rather than by historical precedent.
} 
jurisdictions that are the least hostile to the city population, thus working against finding a housing price effect at the border.

I identify 56 borders in 16 metropolitan areas with block-level data in 1960, at which point the Census Bureau only assigned blocks to central cities and a few large suburban areas. ${ }^{12}$ In 1970 and 1980, I expand the sample to 102 borders in 31 metropolitan areas. ${ }^{13}$ Table 1 lists the metropolitan areas that contribute borders to the sample. The balanced panel (column 1) over-represents large, fragmented cities with populous suburbs. Los Angeles-Orange County and New York City-Northern New Jersey account for nearly 50 percent of the sample. The expanded sample incorporates more geographic diversity, adding smaller college towns like Madison, WI and growing western cities like Las Vegas, NV (column 2). The total number of sample borders from each metropolitan area is listed in column 3, while column 4 lists the number of borders in each area that was excluded due to the presence of an obstruction.

I exclude southern borders from the main analysis for three reasons. First, nearly half of the southern poor were African-American, a group that lacked a secure right to vote until at least 1965. Therefore, the median income of a town's residents is not a good measure of the median income of the local electorate in the South. Second, many southern school districts cover an entire county, including both the central city and its suburban neighbors. Third, southern school districts relied heavily on state and federal funding, rather than on local property tax revenue. As a result, we would not expect to find a relationship between town-level income and housing prices at southern borders through the channel of local tax rates or local public goods. However,

\footnotetext{
${ }^{12}$ To increase the 1960 sample, I include 15 borders that divide two suburbs (e.g., Cambridge-Somerville, MA).

${ }^{13}$ The number of borders in the sample is small relative to the total number of divisions in urban areas. I identified 925 jurisdiction borders in the 16 metropolitan areas that contribute to the panel sample, over 700 of which divided two suburbs. Of the 168 city-suburban borders in these metropolitan areas, 107 included a suburb with 10,000 or more residents and 78 were clear of any obvious obstruction. These 78 borders are included in the sample (56 in the panel sample and 22 from the expanded sample). The average central city in these metropolitan areas bordered on 10.5 suburbs.
} 
if the housing price effect instead reflect confounding factors, like variation in land use policy across town boundaries, we may find similar (spurious) effects in the South. I conduct this placebo exercise using a parallel sample of 49 southern borders in Table 5.

For each sample border, I collect block-level data on the first six blocks away from the border in each direction. Because Census blocks are not digitally mapped for this period, I code the distance of each block from the border by hand. Block data must also be entered by hand for 1960 but are available electronically in 1970 and $1980 .{ }^{14}$ The available block-level variables include mean housing values for owner-occupied units, mean rents for rental units, and a small number of housing quality measures. ${ }^{15}$ Due to confidentiality concerns, housing prices or rents are only published for blocks containing five or more owner-occupied or rental units. I create a measure of the average "user cost" of housing that can be calculated for all blocks in the sample. The user cost is a weighted average of the annual rent paid by renters and the annual borrowing cost paid by homeowners (borrowing cost $=$ home value $x$ interest rate). ${ }^{16}$ Available housing quality controls include the number of units on the block, the average number of rooms by tenure status, the share of units that are in single family structures and the share of residents on the block who are black. ${ }^{17}$

Blocks are matched to the socio-economic characteristics of the jurisdiction in which they are located, including the median income, estimated tax base per resident and poverty rate of

\footnotetext{
${ }^{14}$ Many Ohio counties are unaccountably missing from the 1970 electronic block data. I limit coverage of Ohio to borders in the panel sample or borders for which electronic data is available in 1970 and 1980.

${ }^{15}$ The housing values in the Census are based on owner self-reports, which were validated in Kain and Quigley (1972). An important benefit of the Census, compared to transaction data, is that it covers the full housing stock, rather than selected units that have been put up for sale.

${ }^{16} \mathrm{I}$ use an interest rate of 8 percent for this calculation, which was the average contract mortgage interest rate over the 1960-80 period. Historical mortgage rates are available at http://mortgage-X.com/trends.htm.

${ }^{17}$ The Census of Housing does publish a few other housing attributes at the tract level (for example, the age of the unit and the number of bedrooms and bathrooms). These characteristics are not reported in the block data.
} 
town residents. ${ }^{18}$ I also compile data on property tax rates and municipal expenditures by category. The effective property tax rate is defined as a unit's property tax bill as a share of its market value (rather than as a share of its assessed value). Systematic data on effective property tax rates, drawn from a special survey of recent home sales conducted by the Census of Governments, were only collected in 1970. Because test score data is unavailable during this period, I proxy for school quality with the share of residents holding a college degree. More detail about the sources for the local policy measures is provided in Appendix Table 1.

Appendix Tables 2 and 3 present means and standard deviations of the jurisdiction-level and block-level variables, respectively. In 1970, median family income in sample jurisdictions is $\$ 50,000$ and the average difference in median family income across a sample border is $\$ 10,000$ (in 2000 dollars). There is substantial variation in local policy across borders. Crossing the typical border into the central city results in a 0.7 percentage point increase in property tax rates (measured as a share of the unit's market value) and a $\$ 500$ increase in local government expenditures per capita for non-educational purposes.

Housing units in the border sample have attributes typically associated with the suburban housing stock. In 1970, 76 percent of the units on the average block were detached, single family dwellings. The typical housing unit had 5.7 rooms. Seven percent of residents on the average block were black. However, this value is a weighted average of 25 borders with a high black population share (29.5 percent) and 77 borders with a low black population share ( 0.4 percent). I demonstrate below that the main results are not being driven by the 25 racially diverse borders.

\footnotetext{
${ }^{18}$ I estimated the local property tax base per resident from the Census of Housing. First, I convert annual rents for rental units into likely purchase price using the average price-to-rent ratio for the period ( 5 percent, according to data from the Lincoln Institute of Land Policy). Then, I weight median housing value and median purchase price of rental property by the number of owner-occupied and rental units in the jurisdiction; using mean values would have been more accurate but were not available at the jurisdiction level. Finally, I multiply this weighted value of the average unit by the total number of housing units and divide by the total number of residents to calculate property tax base per resident.
} 


\section{Willingness to Pay for High-income Municipalities}

\section{A. Graphical Evidence of Housing Price and Quality Differences Across Borders and Over Time}

I begin my analysis of the willingness to pay for town-level income with graphical evidence documenting discontinuous shifts in both the level and the growth rate in housing prices across municipal borders. In the cross-section, I classify each jurisdiction pair into a richer and poorer town. In the panel, I instead classify jurisdictions into those with faster and slower income growth over the decade. Figures 1 and 2 present housing prices for the first six block tiers away from the border in either direction. ${ }^{19}$ I designate blocks on the richer (faster growth) side of the border with positive numbers, while blocks on the poorer (slower growth) side are represented with negative numbers.

Figure 1a demonstrates that housing prices on the first block tier of the high-income jurisdiction (block 1) are five percent higher and statistically different from their cross-border neighbor (block -1). In contrast, housing prices on the first block tiers on either side of the border are statistically indistinguishable from adjacent blocks within the same jurisdiction (blocks 1 vs. 2 or blocks -1 vs. -2 ). Figure 2 a presents comparable evidence for the panel specification. There is a clear discontinuity in housing price appreciation at the border, with prices increasing by an additional four percent of housing value between blocks 1 and -1 over the decade. Housing price appreciation is otherwise identical on adjacent blocks within the same jurisdiction. ${ }^{20}$

Figures $1 \mathrm{~b}$ and $2 \mathrm{~b}$ assess the plausibility of the identifying assumption by examining shifts in unit size across municipal borders or changes in unit size across borders over time. In

\footnotetext{
${ }^{19}$ In particular, I graph coefficients from versions of equations 1 and 2 that replace town-level median income with dummy variables for block tiers coded by jurisdiction type (e.g., rich/poor) and distance from the municipal border.

${ }^{20}$ For the cross-section, the p-values for the hypothesis that the first block tiers on either side of the border are equal is 0.00 . In contrast, the p-values when comparing the first to the second block tier inside each jurisdiction (or the second to the third block tier) range from 0.35 to 0.85 . For the panel, the p-value for the cross-border hypothesis is 0.08 and the range for the tests within each jurisdiction is 0.42 to 0.82 .
} 
the cross-section, housing units are somewhat larger on the first block of a wealthy jurisdiction (block 1), with 0.1 additional rooms per unit compared to their cross-border neighbor (block -1). However, in the panel, there is no clear pattern of changes in unit size when crossing the border between jurisdictions with faster or slower income growth. As a result, my preferred results make use of the panel of border areas.

\section{B. Regression Evidence of Housing Quality Differences Across Borders and Over Time}

This section extends the graphical analysis of housing quality across borders by estimating versions of equations 1 and 2 in which the set of housing and neighborhood quality characteristics serve as dependent variables. In each case, I begin with the "Census tract" sample, which contains blocks up to six tiers away from the municipal border, and then consider the "Census block" sample that only includes blocks that are adjacent to the city-suburban border.

The first two columns of Table 2 present coefficients from the cross-section. Census tracts located on the wealthier side of jurisdiction borders have more single family units, a larger number of rooms per unit and fewer black residents. When narrowing the comparison to the block level, most of these differences are cut in half and are no longer statistically significant. It is particularly relevant that there are no cross-border differences in the share of single-family units or in the density of development (housing units per block), two characteristics that are often the target of zoning laws. ${ }^{21}$ However, as was clear in Figure $1 \mathrm{~b}$, wealthy municipality have larger housing units even on the first block adjacent to the border. A $\$ 10,000$ increase in town-level median income (20 percent) is associated with 0.15 additional rooms per unit.

\footnotetext{
${ }^{21}$ In general, higher prices in high-income towns could reflect housing supply restrictions, rather than housing demand. However, there is no evidence of differential housing supply or differential rates of new construction in this narrow cross-border comparison. Therefore, it is reasonable to interpret the coefficients as the reflection of shifts in housing demand along a fixed housing supply curve.
} 
The third and fourth column of Table 2 contain equivalent coefficients for the panel specification. It is worth noting that none of the cross-border differences in changes in housing quality are large or statistically significant. The point estimate on unit size is cut in half at the block level and falls to zero in the tract comparison. One remaining concern is that jurisdictions with larger increases in median income experience less black in-migration over a decade. However, this pattern is driven entirely by a small subset of borders going through a racial transition. If I restrict the sample to the 77 borders with low initial black population shares, the relationship between town-level income and the probability of having a black neighbor disappears. I demonstrate below that the housing price results are equally strong in this subsample (Section IV.D).

\section{Housing Price Gaps Across Jurisdiction Borders and Over Time}

I turn in this section to the core relationship between town-level income and local housing prices. I start in Figure 3 with a graphical exercise relating changes in the suburban housing price premium to changes in the suburban-city income gap over the 1970s. The structure

of Figure 3 is equivalent to the panel regression. In particular, the $\mathrm{X}$-axis indicates a change in the log income gap between a suburb and the neighboring city. Positive values indicate that suburban and city income diverged over the 1970s, while negative values indicate convergence. The Y-axis depicts changes in the suburban housing premium at each border.

Figure 3a reveals a positive relationship between town-level median income and housing prices at the municipal border. A greater divergence of suburban income from the neighboring city is associated with a larger increase in the suburban housing premium. The slope of 0.55 implies that a $\$ 10,000$ (or 20 percent) increase in median income, the typical cross-border 
income gap, is associated with an 11 percent increase in housing prices. This pattern is not driven by any outliers. For comparison, Figure $3 \mathrm{~b}$ examines the relationship between town-level median income and a measure of housing quality (the number of rooms in the average housing unit). The slope of this relationship is nearly flat. A 20 percent increase in median income is associated with the presence of 0.09 of an additional room. The exclusion of one outlier (Allentown-Easton, PA) cuts this relationship in half.

Table 3 contains estimates of the relationship between housing prices and aspects of a town's income distribution (median income, estimated tax base and poverty rates). I begin with a discussion of the median income results in Panel A. In the cross-section, the coefficient in the full block sample implies that a $\$ 10,000$ (or 20 percent) increase in median income is associated with an 8.5 percent increase in housing prices $(=0.43 \cdot 0.2)$. When restricting the sample to blocks adjacent to the border, the implied effect falls to a 7.0 percent increase in housing prices (column 2). Adding the available housing and neighborhood quality controls further reduces the implied effect of a $\$ 10,000$ increase in median income to 4.0 percent (column 3). ${ }^{22}$ The large change in the point estimate with the addition of housing quality controls in the cross-section further motivates the panel analysis.

If the cross-section merely reflected unobserved differences in housing quality, we would expect to find smaller panel coefficients. In contrast, each panel regression produces somewhat larger estimates than its cross-sectional counterpart (columns 4-6). In the block-level comparison, I find that a $\$ 10,000$ increase in median income leads to a 9.6 percent increase in housing prices. Adding block-level controls reduces the implied effect to 7.4 percent. Note that adding block-level controls only reduces the coefficient of interest by 20 percent in the panel

\footnotetext{
${ }^{22}$ The three percentage point decline in the coefficient on median income can be explained by the difference in the number of rooms across borders and the value of an additional room $(0.03=0.2 \log$ point increase in housing value per room $\cdot 0.15$ difference in number of rooms for a 20 percent increase in median income).
} 
regressions (compared to over 40 percent in the cross-section) and that the coefficients with and without block-level controls lie within each other's 95 percent confidence interval.

Panel B replaces median income with a measure of the property tax base per resident at the town level as the main right-hand side variable. In the cross-section, the coefficients on tax base per resident and median income are nearly identical. However, in the panel regressions, the coefficients on tax base are around 40 percent smaller than those on median income. When I include tax base per resident and median income in the same regression, the coefficient on tax base disappears $($ coeff. $=0.064$; s.e. $=0.128)$, while the coefficient on median income only falls somewhat and remains marginally significant $($ coeff. $=0.284 ;$ s.e $=0.195)$. I conclude that one reason why homeowners prefer to live in jurisdictions with high median income residents is because these towns have a higher property tax base. However, there appear to be other attractions of high median income towns, such as higher quality peers in school, which are explored in more detail below.

Panel $\mathrm{C}$ considers the willingness to pay to avoid living in a town with a high poverty rate. $^{23}$ Focusing on the most conservative estimates (those conducted at the block-level with controls for housing quality), I find a coefficient of -0.7 in both the cross-section and panel specifications. The coefficient implies that a five percentage point increase in town-level poverty, roughly equivalent to the gap at the typical border, would lead to a 3.5 percent decline in housing prices. In other words, there is no evidence that homeowners are particularly seeking

\footnotetext{
${ }^{23}$ The concept of an absolute "poverty line," which takes into account family size and the ages of family members, was developed in the 1960s. Thus, the poverty rate regressions include only 1970 and 1980.
} 
to avoid residents at the bottom end of the income distribution but, instead, they appear to respond similarly to high poverty rates and low median income. ${ }^{24}$

\section{Using Subsamples to Examine Alternative Hypotheses}

Thus far, I have documented that the demand for suburban residence increases as the income gap between a city and suburb widens over time. Due to the panel nature of the estimation, this relationship cannot be driven by long-standing differences in the housing stock or neighborhood composition of adjacent areas. However, it could reflect changes in local land use policy or neighborhood composition over the decade. Table 4 casts doubt on this possibility by documenting that the estimated effect of a jurisdiction's median income on housing prices is just as strong in a series of subsamples for which such changes in zoning policy or neighborhood composition are less likely.

Race is the one measure of neighborhood composition available at the block level. For a subset of 25 borders undergoing racial transition, an increase in town-level median income is indeed associated with a relative decline in the probability of having a black neighbor over time. However, there is no such relationship between changes in town-level income and local racial composition for the remaining 77 borders. If the estimated effect of town-level median income on housing prices simply reflected a willingness to pay to avoid black neighbors, we would expect the relationship to be muted in this racially homogenous subsample. In contrast, the effect of median income on housing prices is, if anything, a bit larger for this group (row 2). ${ }^{25}$

\footnotetext{
${ }^{24}$ A portion of the apparent muted response to the poverty rate is due to the time period in which the regression is run. The poverty rate is only measured in 1970 and 1980. When I re-run the median income regression for those years, the coefficient drops by 30 percent to 0.257 (s.e. $=0.173$ ) and is only marginally significant.

${ }^{25}$ In order to include the full sample, I classify initial conditions in 1970 and estimate a panel regression with data from 1970 and 1980.
} 
Although zoning regulations cannot be directly observed in the data, differences in local policy should be reflected in characteristics of the housing stock. In particular, towns with more stringent land use rules should have fewer multi-family units and higher housing prices than their cross-border neighbors. I use these two measures to classify border areas into those more and less likely to have been subject to different land use regimes. If the estimated effect of town-level income on housing prices is driven by differences in land use, we would expect to find weaker results on borders that start out with small initial differences in housing prices or in the share of single-family units. Rows 3 and 4 show that this is not the case. The estimated coefficients in these subsamples (0.45-0.46) are nearly identical to the full sample (0.43).

A placebo sample of southern border areas also cast doubt on the possibility that the estimates can be explained by differences in local land use policy. Southern municipalities had control over their own land use. If the relationship between changes in town-level median income and housing prices were due to changes in local zoning policy, we would expect to find effects of a similar magnitude in the South. However, if the housing price estimate instead driven by local public goods, the effect should be attenuated in the South. First, local funding constituted a smaller share of school revenues in southern districts, which relied more heavily on state and federal funding. In addition, southern cities often shared county-wide school districts with their neighboring suburbs. Moreover, poor (black) residents enjoyed limited voting rights in the South over part of this period. Row 5 reports the estimated effect of changes in town-level median income on changes in housing prices for 49 borders in 10 southern states. In contrast to the main sample, changes in town-level median income are not associated with housing price appreciation in the South. Taken together, these patterns suggest that the main estimates are not 
being driven by confounding differences in zoning regulations or household sorting across borders. ${ }^{26}$

\section{E. Robustness to Alternative Specifications}

Table 5 considers a series of alternative specifications for the panel estimation. The first row reproduces the baseline specification, which weights each observation by the number of owner-occupied housing units on the block. This weighting scheme addresses the fact that the average housing price is calculated more accurately on blocks with a larger number of housing units but it also puts more weight on areas with higher density. The results are not qualitatively changed in rows 2 and 3, which instead weights each block or each border equally. Results are again unchanged in row 4 , which limits the sample to the 56 borders in the balanced panel.

Row 5 re-estimates equation 2 without the 23 California borders. California conducted a major school finance equalization in the 1970s, which may have reduced the willingness of its residents to pay to live in a high-income town or school district. Indeed, I find a somewhat larger value placed on town-level median income outside of California. In a similar fashion, Row 6 drops the 53 borders for which at least one jurisdiction experienced court-ordered school desegregation over the period. ${ }^{27}$ The estimated response to town-level median income is

\footnotetext{
${ }^{26}$ The structure of school finance can explain a portion of the null effect of local median income on housing prices in the South. I gathered data on the sources of school-district revenue from the Elementary and Secondary General Information System (ELSEGIS) in 1970. I divided the twenty states in the main sample into those with "low" and "high" local revenue share; local revenues account for an average of 54 and 70 percent of school expenditures in each group, respectively. I then interacted median income at the jurisdiction level with this state-level local revenue indicator. I find that a $\$ 10,000$ increase in median income is associated with a 8.6 percent increase in housing prices in "high" local revenue states and only a 6.9 percent increase in housing prices in "low" local revenue states. The difference is statistically significant at the five percent level. If these southern states were otherwise identical to "low" local revenues states outside of the South, a $\$ 10,000$ increase in local median income should increase housing prices by 6.9 percent. Instead, I find no effect of local median income on housing prices in the South. Therefore, I conclude that the system of school finance can explain 20 percent of this null effect $(=[8.6-6.9] / 8.6)$.

${ }^{27}$ I collect data on the presence of desegregation court-orders by school district from the State of Public School Integration website (Logan, 2004). The site contains the full text of judicial decisions and enumerates each action that a district was required to take to counteract desegregation. I classify any school district that was required by the
} 
unchanged, suggesting that income is not simply proxying for the desire to avoid integrated schools. $^{28}$

Rows 7 and 8 consider the rents and the user cost of housing as alternative measures of the willingness to pay for town-level income. Rental prices are not as responsive to town-level median income - compare the implied 6.2 percent increase in rents to the 9.6 percent increase in housing values for a $\$ 10,000$ increase in median income. The weaker response may be due to the composition of the rental market; renters tend to be younger, less well-off, and less likely to have children. In addition, unlike rents, housing prices might also incorporate expectations of future income divergence between a city and its suburbs. The presence of rent control in some urban areas may also limit the ability of the rental market to adjust through prices. Due to the Census Bureau's data restrictions, only a subset of sample blocks have available data on average rental rates or housing values. Row 8 incorporates a measure of the user cost of housing, which allows the inclusion of all housing units along the border in all years. The implied effect of town-level median income on user costs is larger than on either housing values or rents alone. ${ }^{29}$

The coefficient in Row 9 is from a regression that, in addition to median income, includes two town-level characteristics on the right-hand side: black population share and the share of the population over 65 years of age. Others have found that racially fragmented cities and cities with a larger elderly population spend a smaller share of their budget on public goods (Alesina, Baqir and Easterly, 1999; Cutler, Elmendorf and Zeckhauser, 1993). However, adding these town-level

court to engage in at least one remedial step to address school segregation between 1960 and 1980 as a "desegregated" district and drop any border for which at least one jurisdiction falls into this category. Boustan (2010) explores the effect of school desegregation on housing prices during this period in more detail.

${ }^{28}$ A further concern is that the results are not generalizable to smaller suburbs because the sample is limited to suburbs with at least 10,000 residents. To assess the importance of town size, I subdivide the sample into borders with suburbs above and below the median population in $1970(=60,000$ residents). The coefficients on $\ln (\mathrm{median}$ income) were nearly identical in the two subsamples -0.349 (s.e. $=0.215$ ) for borders with smaller suburbs and 0.387 (s.e. $=0.154$ ) for the borders with larger suburbs.

${ }^{29}$ Note that the coefficient on user costs is not itself a weighted average of the housing price and rental estimates because many blocks have both owner-occupied and rental housing. 
correlates has no effect on the relationship between median income and housing prices. Furthermore, the local black population share has no effect on housing prices after control for the median income of the town's residents.

Row 10 instead interacts the local median income with the black population share of the central city. In this case, the main effect of local median income disappears and, instead, I find a large and significant interaction term between median income and the city's black population share. The interaction term implies that, in a metropolitan area anchored by a city with the mean black population share $(0.184)$, a $\$ 10,000$ increase in median income in a neighboring suburb would increase housing prices there by 2.9 percent $(=0.184 \cdot 0.2 \cdot 0.797)$. With a one-standard deviation increase in the city's black population share $(0.355)$, the same increase in median income would be associated with a 5.6 percent increase in housing prices $(0.355 \cdot 0.2 \cdot 0.797)$. In other words, for a given city-suburban income gap, residents are more willing to pay to live in a high-income suburb in metropolitan areas anchored by a racially diverse central city. This pattern is consistent with the hypothesis that residents are less willing to pay for the public services of residents of a different race.

\section{The Role of Public Goods in the Demand for High-income Municipalities}

The desire to live in a wealthy town, above and beyond the demand for wealthy neighbors, is likely driven by differences in local public goods and local tax rates. This section considers a series of local policies that may account for the estimated demand for living in a wealthy town.

I begin in Table 6 by assessing whether rich and poor towns offer different bundles of tax rates and local public goods. In particular, following the structure of equation 1, I regress a series 
of local policy variables on town-level median income and a vector of border area dummy variables in 1970. I focus on this cross-section because 1970 is the only year in which data on effective property tax rates were collected. I find that high-income towns differ from their poorer neighbors in three ways: first, they set lower property tax rates. An additional $\$ 10,000$ of townlevel median income is associated with a 0.52 percentage point reduction in the effective property tax rate. Secondly, wealthy municipalities spend less than poor cities on noneducational functions, particularly on public safety, perhaps because they face fewer social problems. Finally, a larger share of residents in high-income towns hold a college degree, a potential proxy for higher peer quality in local public schools. However, wealthy towns do not allocate more funds to educational expenditures per pupil overall; nor do they spend more on fire protection, parks, road maintenance or sanitation services by town income (not shown). ${ }^{30}$

Table 7 then considers whether differences in local policy can account for the estimated willingness to pay to live in a high-income town. The first panel of Table 7 explores the relationship between housing values and each local policy variable in turn. For such policy variables to explain the relationship between jurisdiction income and housing prices, one necessary condition is that homeowners must value the policy. I find that home values fall by 6.5 percent for every percentage point increase in the property tax rate. By this measure, a homeowner would break even after eight years by purchasing a more expensive home in a jurisdiction with a lower tax rate. Towns with a higher density of college graduates have higher home values at the border, lending credence to the notion that the college share of the population is a proxy for higher quality in public schools. Perhaps surprisingly, home values decline with

\footnotetext{
${ }^{30}$ It is important to note that higher expenditures may not translate into a higher quality or quantity of public services. First, the majority of expenditures cover the wages and salaries of municipal workers, an increase in which may not translate into a higher quality of service provision. Second, municipal services are not equally provided to every neighborhood but may be directed at either low- or high-income areas.
} 
total municipal expenditures or additional spending on public safety. These estimates may reflect the fact that these expenditures are disproportionately directed toward needy neighborhoods, rather than toward border areas; residents at the border prefer not to pay to police someone else's neighborhoods.

The second panel of Table 7 adds each of these local policies to the regression of home values on median income. Policies that explain a portion of the willingness to pay for wealthy co-residents should reduce the main coefficient on median income. For comparison, the first column re-estimates equation 1 for the 61 borders with available data on all local policy measures in 1970 . The resulting coefficient (0.260) implies that $\$ 10,000$ increase in median income raises housing values by 5.2 percent in this subsample. Including the property tax rate as an additional regressor reduces the coefficient of interest to 0.18 . The coefficient also falls when the town's share of college graduates is added. When both the property tax rate and college share are included, the coefficient on median income falls to 0.13 and is no longer statistically significant. I conclude that higher school quality and lower property tax rates can account for 20 percent and 30 percent of the estimated demand for living in a wealthy town, respectively. Neither the level of total non-educational spending nor spending earmarked for public safety help to explain the demand for high-income towns. I conclude that the desire to live in a wealthy town stems from two main (measurable) factors: lower property tax rates set by jurisdictions with a higher tax base, and higher school quality in wealthier districts, as proxied by a higher college share, despite equal expenditures per pupil. 


\section{Conclusion}

This paper estimates the demand for living in a high-income town by observing changes in the premium for suburban housing as the city-suburban income gap widens (or narrows) over time. I focus on changes over time in the price of neighboring housing units on opposite sides of city-suburban borders. Local public goods and tax rates change sharply at these borders, while changes in housing and neighborhood quality evolve more continuously over space. I find that the marginal homeowner is willing to pay seven percent more for an otherwise equal housing unit located in a town whose median income was $\$ 10,000$ above the neighboring city. This premium can be largely explained by the fact that jurisdictions with a higher tax base set lower property tax rates and offer higher school quality.

The total demand for living in a high-income suburb is driven both by local political economy and neighborhood quality. Bayer, Ferreira and McMillan (2007) document that housing values increase by six percent for a $\$ 10,000$ increase in the income of immediate neighbors. My estimates suggest that, controlling for immediate neighborhood, housing values would increase by 7.4 percent for a $\$ 10,000$ increase in town-level median income. Overall, it appears that the marginal homebuyer is willing to pay up to 13 percent more for an equivalent house located in a high-income town surrounded by high-income neighbors $(=6.0+7.4)$.

The demand for wealthy co-residents can, in theory, act as a "suburban multiplier," augmenting the response to other urban shocks. For example, the construction of the interstate highway system contributed to suburbanization during this period (Baum-Snow, 2007). If the presence of a new highway encouraged households in the top half of the income distribution to leave the city, the resulting change in average household income in the city would further reduce demand for urban residence. A feedback effect of this nature may help explain the rapid decline 
of American central cities in the 1960s and 1970s (Baumol, 1967). More speculatively, this type of multiplier may be at work in the opposite direction today as some cities undergo a process of gentrification. In this case, rising incomes spurred by the return to the city of educated young workers and wealthy empty-nesters could form the basis of an urban revival. 


\section{Bibliography}

Alesina, Alberto, Reza Baqir, and William Easterly. "Public Goods and Ethnic Divisions." Quarterly Journal of Economics, 114(4), 1999, p. 1243-1284.

Barrow, Lisa and Cecilia Elena Rouse. "Using Market Valuation to Assess Public School Spending.” Journal of Public Economics, 88, 2004, p. 1747-1769.

Baum-Snow, Nathaniel. "Did Highways Cause Suburbanization?" Quarterly Journal of Economics, 2007, p. 775-805.

Baumol, William. "The Macroeconomics of Unbalanced Growth: The Anatomy of Urban Crisis." American Economic Review, 57(3), June 1967, p. 415-426.

Bayer, Patrick, Fernando Ferreira, and Robert McMillan. "A Unified Framework for Measuring Preferences for Schools and Neighborhoods." Journal of Political Economy, 2007, p. 588-638.

Black, Sandra. "Do Better Schools Matter? Parental Valuation of Elementary Education." Quarterly Journal of Economics, 114(2), 1999, p. 577-599.

Boustan, Leah Platt. "Was Postwar Suburbanization 'White Flight"? Evidence from the Black Migration.” Quarterly Journal of Economics, 2010, p. 417-443.

Boustan, Leah Platt. "School Desegregation and Urban Change: Evidence from City Boundaries.” American Economic Journal: Applied Economics, 4(1), 2012, p. 85-108.

Buchanan, James and Charles Goetz. "Efficiency Limits of Fiscal Mobility: An Assessment of the Tiebout Model.” Journal of Public Economics, 1972, p. 25-44.

Calabrese, Stephen, Dennis Epple, Thomas Romer and Holger Sieg. "Local Public Good Provision: Voting, Peer Effects, and Mobility.” Journal of Public Economics, 2006, p. 959-81.

Chay, Kenneth and Michael Greenstone. "Does Air Quality Matter? Evidence from the Housing Market." Journal of Political Economy. 113(2), 2005, p.

Cullen, Julie Berry and Steven D. Levitt. "Crime, Urban Flight, and the Consequences for Cities." Review of Economics and Statistics, 81(2), 1999, pp. 159-169.

Cutler, David M., Douglas W. Elmendorf, and Richard Zeckhauser. "Demographic Characteristics and the Public Bundle.” Public Finance, 48, 1993, p. 178-198.

Ellickson, Bryan. "Jurisdictional Fragmentation and Residential Choice." American Economic Review, Papers and Proceedings, 61, 1971, p. 334-339.

Epple, Dennis and Glenn Platt. "Equilibrium and Local Redistribution in an Urban Economy When Households Differ in Both Preferences and Incomes." Journal of Urban Economics, 1998. 
Epple, Dennis and Thomas Romer. "Mobility and Redistribution." Journal of Political Economy, 99(4), 1991, p. 828-858.

Epple, Dennis and Holger Sieg. "Estimating Equilibrium Models of Local Jurisdictions." Journal of Political Economy, 107(4), 1999, p. 645-681.

Fernandez, Raquel and Richard Rogerson. "Income Distribution, Communities, and the Quality of Public Education." Quarterly Journal of Economics, 111(1), 1996, 135-64.

Figlio, David and Maurice Lucas. "What's in a Grade? School Report Cards and the Housing Market.” American Economic Review, 94(3), 2004, p. 591-604.

Gibbons, Stephen, Stephen Machin and Olmo Silva. "Valuing School Quality Using Boundary Discontinuities." SERC Discussion Paper 0018, 2009.

Glaeser, Edward L. and Joseph Gyourko. "Urban Decline and Durable Housing." Journal of Political Economy, 113(2), 2005, p. 345-375.

Glaeser, Edward L. Matthew E. Kahn, and Jordan Rappaport. "Why Do the Poor Live in Cities?" Journal of Urban Economics, 63, 2008, p. 1-24.

Greenstone, Michael and Justin Gallagher. "Does Hazardous Waste Matter? Evidence from the Housing Market and the Superfund Program." Quarterly Journal of Economics. 2008, p. 9511003.

Ioannides, Yannis and Jeffrey Zabel. "Neighborhood Effects and Housing Demand." Journal of Applied Econometrics. 2003, p. 563-584.

Hamilton, Bruce W. "Capitalization of Intrajurisdictional Differences in Local Tax Prices." American Economic Review, 66(5), 1976, p. 743-753.

Henderson, J. Vernon. "The Impact of Zoning Policies Which Regulate Housing Quality." Journal of Urban Economics, 1985, p. 302-312.

Jackson, Kenneth T. Crabgrass Frontier: The Suburbanization of the United States. New York: Oxford University Press, 1985.

Kain, John F. and John M. Quigley. "Housing Market Discrimination, Home Ownership, and Savings Behavior.” American Economic Review, 62, 1972, p. 263-277.

Kane, Thomas J., Douglas O. Staiger and Gavin Samms. "School Accountability Ratings and Housing Values." In William Gale and Janet Rothenberg Pack (eds.) Brookings-Wharton Papers on Urban Affairs, 2003 pp. 83-138.

Keating, Ann Durkin. Building Chicago: Suburban Developers and the Creation of a Divided Metropolis. Columbus: Ohio State University Press, 1988. 
Kopecky, Karen and Ming Hong Suen. "A Quantitative Analysis of Suburbanization and the Diffusion of the Automobile.” International Economic Review, 51(4), 2010, p. 1003-37.

Logan, John. 2004. "Desegregation Court Cases." The State of Public School Integration. Brown University. <http://www.s4.brown.edu/schoolsegregation/desegregationdata.htm.>

Lee, David S. and Thomas Lemieux. "Regression Discontinuity Designs in Economics." Journal of Economic Literature, 48(2), 2010, p. 281-355.

LeRoy, Stephen and John Sonstelie. "Paradise Lost and Regained: Transportation Innovation, Income and Residential Location.” Journal of Urban Economics, 13, 1983, p. 67-89.

Machin, Stephen and Kjell G. Salvanes. "Valuing School Quality via a School Choice Reform." IZA Discussion Paper No. 4719. January 2010.

Metzler, Jeffrey. "Inequitable Equilibrium: Education Finance in the United States." Indiana Law Review. 36, 2003.

Reback, Randall. "House Prices and the Provision of Local Public Services: Capitalization Under School Choice Programs.” Journal of Urban Economics, 57(2), 2005, p. 275-301.

Rosen, Sherwin. "Hedonic Prices and Implicit Markets: Product Differentiation in Pure Competition.” Journal of Political Economy, 82, 1974, p. 34-55.

Tiebout, Charles M. "A Pure Theory of Local Expenditures." Journal of Political Economy. 64(5), 1956, p. 416-424.

Turner, Matthew A., Andrew Haughwout and Wilbert van der Klaauw. "Land Use Regulation and Welfare." Manuscript, 2011.

U.S. Bureau of Census. $18^{\text {th }}$ and $19^{\text {th }}$ Census of Housing: 1960, 1970. Various cities by census tracts and blocks, Washington: Government Printing Office.

U.S. Bureau of Census. Census of Governments, 1967, 1972. Washington: Government Printing Office.

U.S. Bureau of the Census. County and City Data Book, Consolidated File: City/County Data, 1947-1977 [computer file], ICPSR Study 7735-7736. Ann Arbor, MI: Inter-university Consortium for Political and Social Research, 2000.

U.S. Department of Education. Elementary and Secondary General Information System (ELSEGIS): Public Elementary-Secondary School Systems-Finances, various years [computer file]. Ann Arbor, MI: Inter-university Consortium for Political and Social Research, 2003.

Westhoff, Frank. "Existence of Equilibria in Economies with a Local Public Good." Journal of Economic Theory, 14, 1977, p. 84-112. 
Wheaton, William C. "Land Capitalization, Tiebout Mobility and the Role of Zoning Regulations." Journal of Urban Economics, 34(2), 1993, p. 102-117. 
Figure 1: Housing values and unit size by distance to the jurisdiction border, Poorer vs. richer towns. Pooled cross-section, 1960-80

\section{a. Housing values}

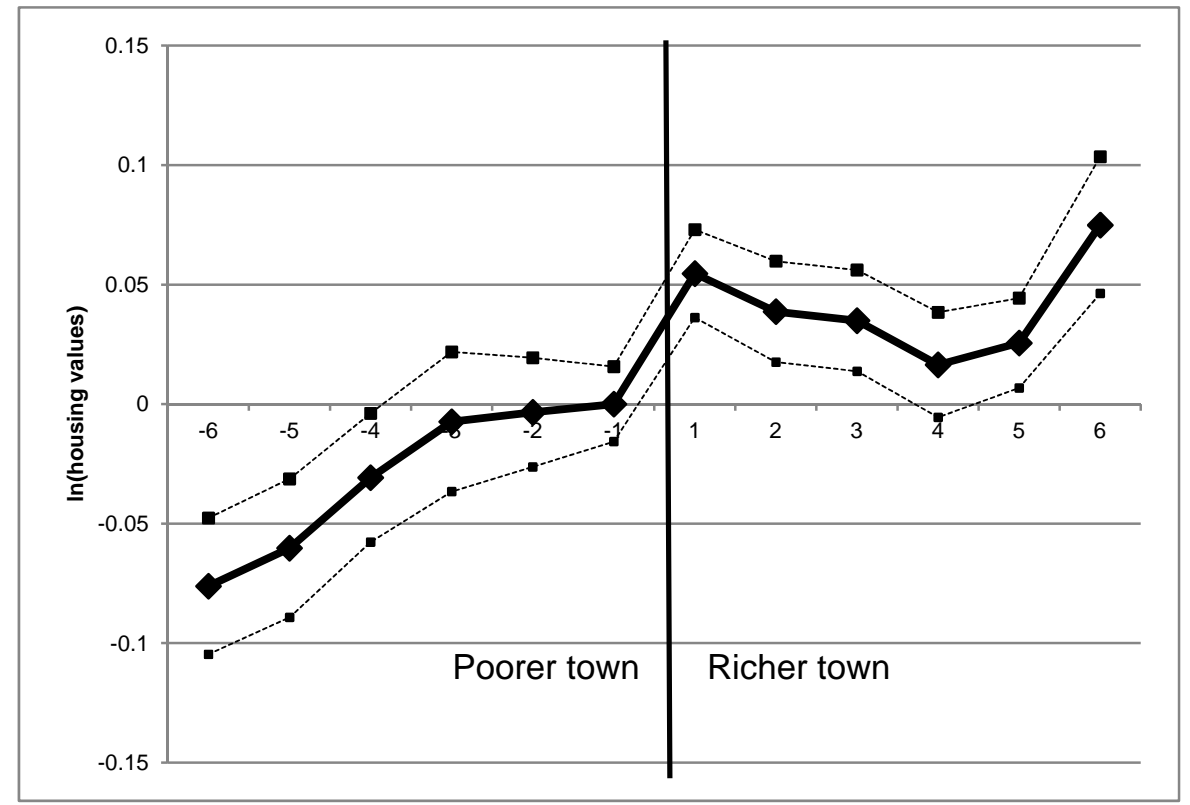

\section{b. Average number of rooms per owner-occupied housing unit}

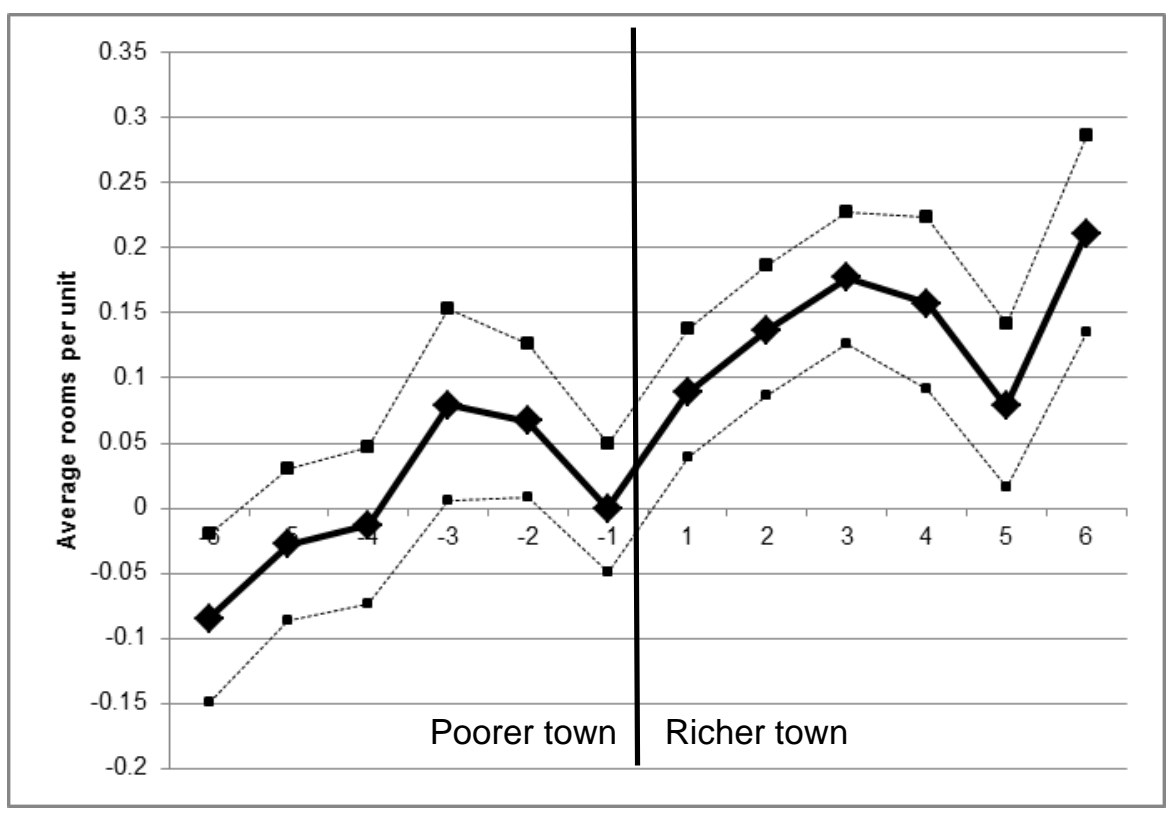

Notes: Each dot is a coefficients from a version of equation 1 that replaces the town-level median income with a vector of dummy variables for block tiers, coded by distance from the municipal border. I classify the jurisdictions in each border area as either "rich" or "poor." Tier numbers range between 6 and -6 with positive numbers falling on the rich side of the border and higher numbers (in absolute value) indicating distances further from the border. Estimates are relative to the first block tier on the poor side. Dotted lines indicate 95 percent confidence intervals. 
Figure 2: Changes in housing values and unit size by distance to the jurisdiction border, Towns with faster vs. slower income growth. Panel, 1960-80

\section{a. Changes in housing values}

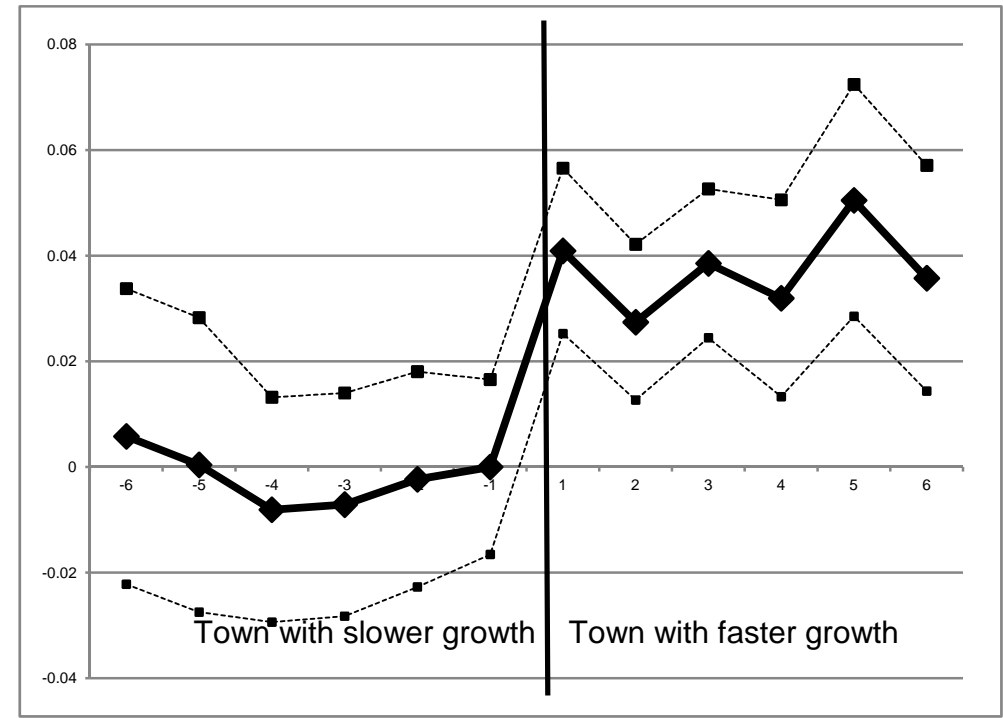

b. Changes in average number of rooms per owner-occupied housing unit

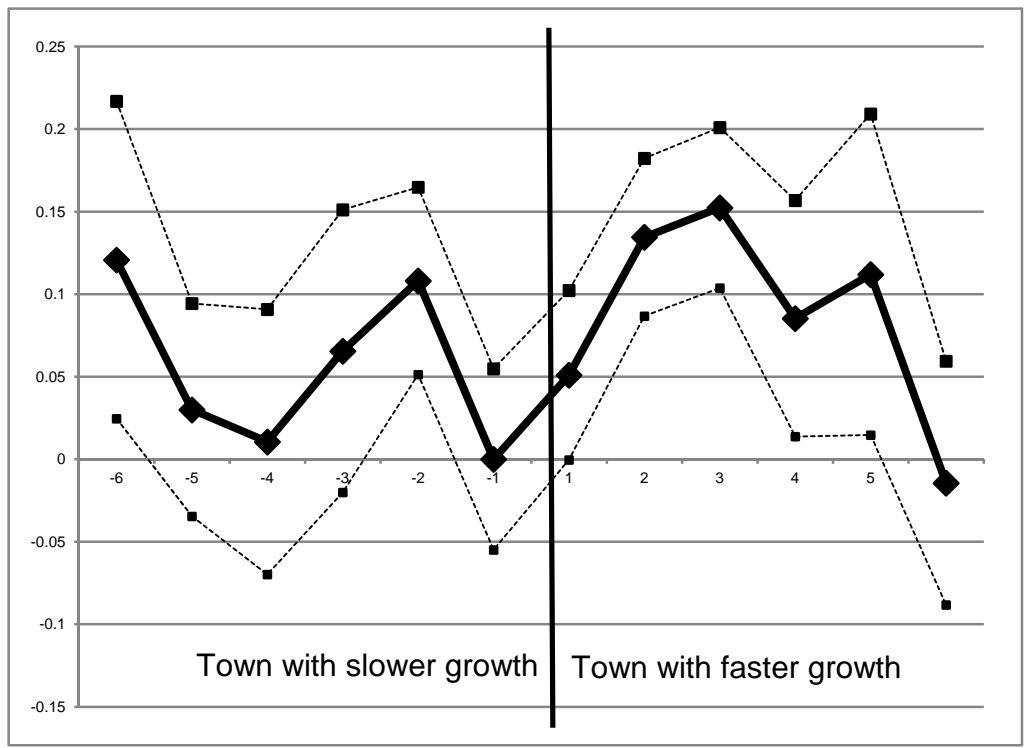

Notes: Each dot is a coefficient on interactions from a version of equation 2 that replaces the town-level median income with dummy variables for block tiers and interactions between block tiers and Census year. I classify the jurisdictions in each border area as either experiencing higher or lower income growth in relative terms over a decade. Tier numbers range between 6 and -6 with positive numbers falling on side of the border with higher income growth and higher numbers (in absolute value) indicating distances further from the border. Estimates are relative to the first block tier on the poor side. Dotted lines indicate 95 percent confidence intervals. 
Figure 3: Relationship between changes in the city-suburban income gap and changes in housing unit size at city-suburban borders, 1970-80

\section{a. Housing values}

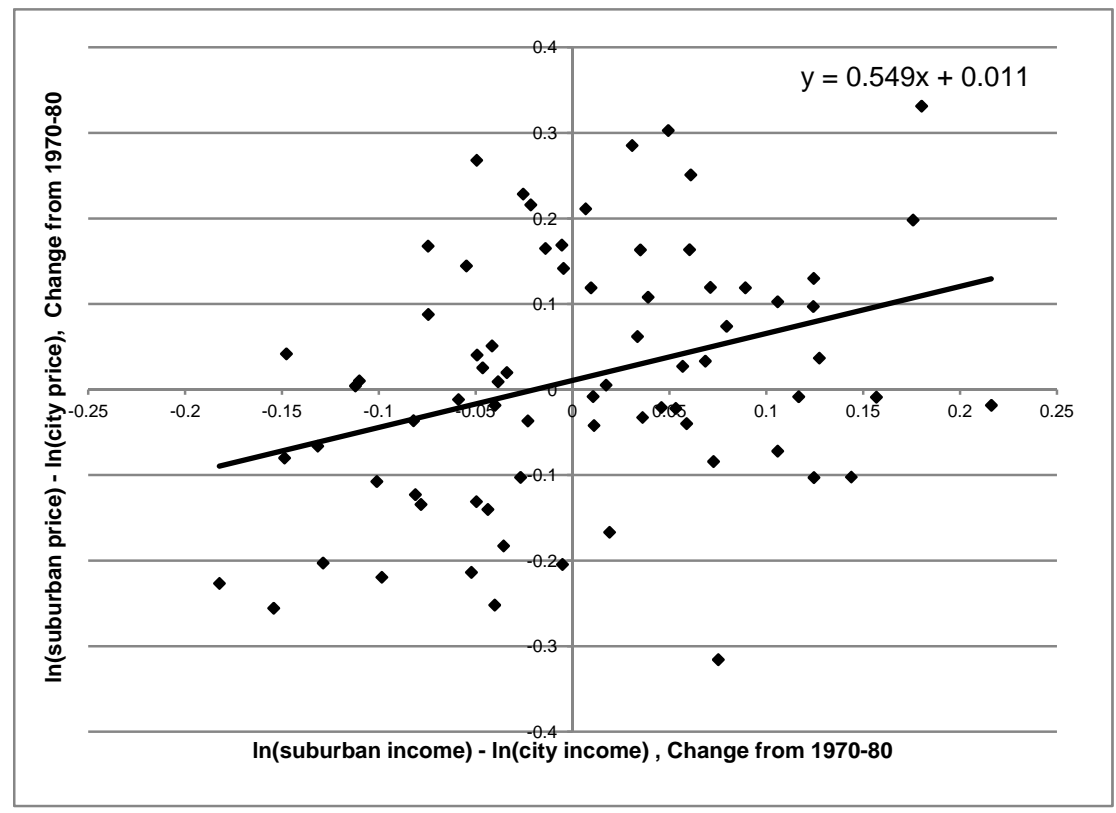

b. Average number of rooms per owner-occupied housing unit

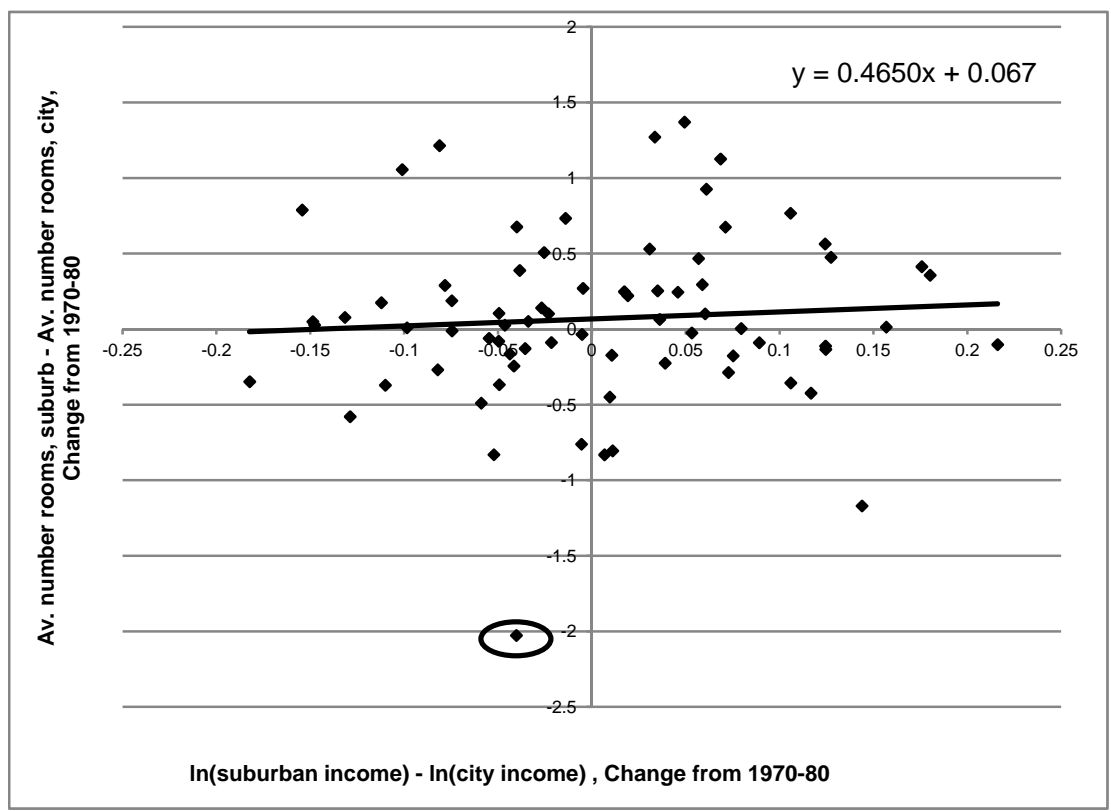

Notes: Each dot represents a border area. The X-axis indicates a change in the log income gap between a suburb and its city from 1970 to 1980 . The Y-axis depicts changes in the suburban housing premium (panel A) or the suburban unit size premium (panel B) over the decade. 
Table 1: Jurisdiction borders with available block-level data by metropolitan area, 1960-80

\begin{tabular}{|c|c|c|c|c|c|}
\hline \multirow[b]{2}{*}{ Region } & \multirow[b]{2}{*}{ Metropolitan area } & \multicolumn{4}{|c|}{ Number of borders } \\
\hline & & $\begin{array}{l}\text { Sample, } \\
1960-80\end{array}$ & $\begin{array}{c}\text { Added to } \\
\text { sample, } \\
1970-80 \\
\end{array}$ & $\begin{array}{c}\text { Sample, } \\
\text { total }\end{array}$ & Excluded \\
\hline \multirow[t]{8}{*}{ North } & Allentown-Bethlehem, PA & & 2 & 2 & \\
\hline & Boston, MA & 2 & 1 & 3 & 4 \\
\hline & Hartford, CT & & 3 & 3 & 2 \\
\hline & New York, NY-NJ ${ }^{\dagger}$ & 10 & & 10 & 3 \\
\hline & Pittsburgh, PA & 3 & & 3 & \\
\hline & Providence, RI & 3 & 1 & 4 & \\
\hline & Scranton, PA & & 1 & 1 & \\
\hline & Springfield, MA & & 1 & 1 & 1 \\
\hline \multirow[t]{15}{*}{ Midwest } & Akron, $\mathrm{OH}$ & & 2 & 2 & 2 \\
\hline & Canton, $\mathrm{OH}$ & & 1 & 1 & \\
\hline & Chicago, $\mathrm{IL}^{\dagger}$ & 5 & 2 & 7 & 6 \\
\hline & Cleveland, $\mathrm{OH}$ & 2 & & 2 & \\
\hline & Dayton, $\mathrm{OH}$ & 1 & & 1 & \\
\hline & Des Moines, IA & & 2 & 2 & \\
\hline & Detroit, MI & 1 & 6 & 7 & \\
\hline & Grand Rapids, MI & & 4 & 4 & \\
\hline & Indianapolis, IN & & 1 & 1 & 3 \\
\hline & Kansas City, KS-MO & 2 & 2 & 4 & 3 \\
\hline & Madison, WI & & 1 & 1 & \\
\hline & Minneapolis/St. Paul, MN & 1 & 1 & 2 & 3 \\
\hline & Moline-Davenport, IL-IA & 1 & 1 & 2 & \\
\hline & South Bend, IN & & 1 & 1 & \\
\hline & St. Louis, MO & 1 & & 1 & 4 \\
\hline \multirow[t]{9}{*}{ West } & Denver, CO & 1 & 2 & 3 & \\
\hline & Las Vegas, NV & & 1 & 1 & \\
\hline & Los Angeles, $\mathrm{CA}^{\dagger}$ & 17 & 5 & 22 & 7 \\
\hline & Phoenix, AZ & & 1 & 1 & 1 \\
\hline & Portland, OR & & 2 & 2 & 1 \\
\hline & $\begin{array}{l}\text { San Bernard.-Riverside, } \\
\text { CA }\end{array}$ & & 1 & 1 & 3 \\
\hline & San Francisco, $\mathrm{CA}^{\dagger}$ & 2 & 1 & 3 & \\
\hline & San Jose, CA & 4 & & 4 & \\
\hline & TOTAL: & 56 & 46 & 102 & 44 \\
\hline
\end{tabular}

Notes: Metropolitan areas marked with ${ }^{\dagger}$ contained secondary central cities in 1960 that are now considered by the Census Bureau to anchor their own, independent metropolitan areas. These are: Newark, NJ; Jersey City, NJ; and Clifton, NJ (New York); Gary, IN (Chicago); Anaheim, CA (Los Angeles); and Oakland, CA (San Francisco). 


\section{Table 2: Effect of jurisdiction-level median income on housing quality and neighborhood demographics}

\begin{tabular}{l|cccc}
\hline \multirow{2}{*}{ Dependent variable } & \multicolumn{2}{|c}{ Cross-section } & \multicolumn{2}{c}{ Panel } \\
\hline Share single family & Tract & Block & Tract & Block \\
& 0.070 & 0.034 & -0.135 & -0.183 \\
& $(0.035)$ & $(0.050)$ & $(0.079)$ & $(0.141)$ \\
Number units & -13.073 & -14.227 & 4.971 & 9.029 \\
& $(10.059)$ & $(21.352)$ & $(23.912)$ & $(47.062)$ \\
Number rooms & 0.765 & 0.779 & 0.009 & 0.344 \\
& $(0.160)$ & $(0.199)$ & $(0.307)$ & $(0.439)$ \\
Share black & -0.086 & -0.036 & -0.354 & -0.164 \\
& $(0.047)$ & $(0.022)$ & $(0.233)$ & $(0.147)$ \\
$N$ & 20,336 & 6,358 & 20,336 & 6,358 \\
\hline
\end{tabular}

Notes: Columns 1 and 2 (columns 3 and 4) report coefficients and standard errors from separate regressions of equation 1 (equation 2) with each block-level characteristic as the dependent variable. Standard errors are clustered by border area. There are 102 border areas included in the regressions (see Table 1). Observations are weighted by the number of owner-occupied units on the block. Columns marked "tract" contain blocks in the first six tiers on either side of the border, while columns marked "block" contain only blocks adjacent to the border. The sample is restricted to blocks with at least five owner-occupied units without missing information on housing values. 


\section{Table 3: Effect of jurisdiction-level income on housing prices}

Dependent variable $=\ln$ (value of owner-occupied units)

\begin{tabular}{|c|c|c|c|c|c|c|}
\hline & \multicolumn{3}{|c|}{ Cross section } & \multicolumn{3}{|l|}{ Panel } \\
\hline & Tract & Block & $\begin{array}{l}\text { Block, } \\
\text { controls }\end{array}$ & Tract & Block & $\begin{array}{l}\text { Block, } \\
\text { controls }\end{array}$ \\
\hline $\begin{array}{l}\text { Panel A } \\
\ln (\text { median income })\end{array}$ & $\begin{array}{c}0.425 \\
(0.060)\end{array}$ & $\begin{array}{c}0.348 \\
(0.058)\end{array}$ & $\begin{array}{c}0.197 \\
(0.036)\end{array}$ & $\begin{array}{c}0.552 \\
(0.190)\end{array}$ & $\begin{array}{c}0.480 \\
(0.170)\end{array}$ & $\begin{array}{c}0.371 \\
(0.127)\end{array}$ \\
\hline$N$ & 20,348 & 6,358 & 6,358 & 20,348 & 6,358 & 6,358 \\
\hline $\begin{array}{l}\text { Panel B } \\
\ln (\text { tax base per resident })\end{array}$ & $\begin{array}{c}0.504 \\
(0.074)\end{array}$ & $\begin{array}{c}0.276 \\
(0.052)\end{array}$ & $\begin{array}{c}0.157 \\
(0.039)\end{array}$ & $\begin{array}{c}0.315 \\
(0.125)\end{array}$ & $\begin{array}{c}0.224 \\
(0.118)\end{array}$ & $\begin{array}{c}0.181 \\
(0.096)\end{array}$ \\
\hline$N$ & 17,888 & 5,509 & 5,509 & 17,888 & 5,509 & 5,509 \\
\hline $\begin{array}{l}\text { Panel C } \\
\text { Share poverty }\end{array}$ & $\begin{array}{l}-1.428 \\
(0.277)\end{array}$ & $\begin{array}{l}-1.045 \\
(0.237)\end{array}$ & $\begin{array}{l}-0.694 \\
(0.170)\end{array}$ & $\begin{array}{l}-0.922 \\
(0.624)\end{array}$ & $\begin{array}{l}-0.948 \\
(0.550)\end{array}$ & $\begin{array}{l}-0.671 \\
(0.460)\end{array}$ \\
\hline$N$ & 16,144 & 4,844 & 4,844 & 16,144 & 4,844 & 4,844 \\
\hline
\end{tabular}

Notes: Cells contain coefficients and standard errors from regressions of housing prices on jurisdiction-level income measures (cross-section = equation 1; panel = equation 2). Standard errors are clustered by border area. The median income and tax base regressions contain data from 1960 to 1980, while poverty rates are only available in 1970 and 1980. Block-level control variables include: number of housing units on block; share of units that are single-family structures; average number of rooms; and black population share. See the notes to Table 2 for other details on the samples and specifications. 


\section{Table 4: Effect of jurisdiction-level median income on housing prices in various subsamples}

\begin{tabular}{|c|c|}
\hline & $1970-80$ \\
\hline 1. Baseline & 0.431 \\
\hline$N=4,854$ & $(0.189)$ \\
\hline \multicolumn{2}{|l|}{ Sub-samples } \\
\hline 2. $<75^{\text {th }^{\mathrm{h}}}$ percentile, $\%$ black & 0.521 \\
\hline$N=3,593$ & $(0.255)$ \\
\hline 3. $<$ median, initial price gap & 0.464 \\
\hline$N=2,455$ & $(0.176)$ \\
\hline 4. $<$ median, initial single family gap & 0.452 \\
\hline$N=2,537$ & $(0.287)$ \\
\hline \multicolumn{2}{|l|}{ Southern sample $($ Borders $=49)$} \\
\hline 5. Southern & 0.019 \\
\hline$N=2,329$ & $(0.062)$ \\
\hline
\end{tabular}

Notes: Cells contain coefficients and standard errors from panel regressions of housing prices on jurisdiction-level median income (equation 2). See the notes to Tables 2 and 3 for details on the sample and specification. In order to calculate initial characteristics for each border area, analysis is restricted to 1970 and 1980 . In 1970 , the $75^{\text {th }}$ percentile of initial black population share is 3.6 percent; the median initial housing price gap is 12.5 percent and the initial gap in single family share is 9.5 percentage points. 
Table 5: Effect of jurisdiction-level median income on housing prices, Alternative specifications

\begin{tabular}{lc}
\multicolumn{2}{c}{ Dependent variable $=\ln ($ value of owner occupied units) } \\
\hline & $1960-80$ \\
\hline 1. Baseline & 0.480 \\
$N=6,358$ & $(0.170)$ \\
& \\
2. Unweighted & 0.491
\end{tabular}

3. Weight borders equally $\quad 0.516$

4. Balanced panel $\quad 0.518$

$N=4,417$

5. Drop California $\quad 0.697$

$N=3,850$

6. Drop if desegregate $\quad 0.509$

$N=2,911$

7. Dependent variable $=\ln ($ rent $) \quad 0.308$

$N=4,487$

8. Dependent variable $=\ln ($ user cost $)$

$N=7,804$

9. Add jurisdiction controls $\quad 0.545$

$(0.142)$

10. Interact with \% black in city

Main effect $\quad-0.013$

Interaction $\quad 0.797$

(0.339)

Notes: Cells contain coefficients and standard errors from panel regressions of housing prices on jurisdiction-level median income (equation 2; see Table 3, column 5). The notes to Tables 2 and 3 provide details on the sample and specification. The regressions underlying rows 4-6 contain 56, 79 and 49 border areas respectively. Row 7 (row 8) includes all blocks with at least five rental (occupied) units and is weighted by the number of rental (occupied) units. Row 9 includes as regressors the black population share and share of the population over 65 years old at the townlevel. Row 10 interacts $\ln$ (median income) at the town level with the black population share of the central city. The black population share itself is a characteristic shared between both jurisdictions at the border and therefore is absorbed into the border area dummy variable. 
Table 6: Association between jurisdiction-level median income and local policy, 1970

\begin{tabular}{|c|c|c|c|c|c|c|}
\hline \multirow[b]{3}{*}{ RHS variable } & \multicolumn{6}{|c|}{ Dependent variables } \\
\hline & Property & Share & Spending & 0 per cap.) & Spending ( & per pupil) \\
\hline & tax rate & college & Total & Police & Instruct & Admin. \\
\hline $\ln ($ med income $)$ & $\begin{array}{l}-2.681 \\
(0.325)\end{array}$ & $\begin{array}{c}0.276 \\
(0.032)\end{array}$ & $\begin{array}{l}-1.374 \\
(0.235)\end{array}$ & $\begin{array}{c}-0.214 \\
(0.025)\end{array}$ & $\begin{array}{l}-0.169 \\
(0.385)\end{array}$ & $\begin{array}{l}-0.047 \\
(0.045)\end{array}$ \\
\hline Borders & 62 & 102 & 96 & 96 & 102 & 102 \\
\hline Observations & 124 & 204 & 192 & 192 & 204 & 204 \\
\hline
\end{tabular}

Notes: Cells contain coefficients and standard errors from regressions of local policy measures on jurisdiction-level median income. The unit of observation is a jurisdiction. Following the format of equation 1, the regressions also contain a vector of border area dummy variables. Sources for the local policy measures are reported in Appendix Table 1. 
Table 7: Explaining the willingness to pay for jurisdiction-level income with variation in local policy, 1970

Dependent variable $=\ln$ (value of owner-occupied units)

\begin{tabular}{|c|c|c|c|c|c|c|}
\hline & \multirow[t]{2}{*}{ Alone } & \multirow[t]{2}{*}{$\begin{array}{l}\text { Property } \\
\text { tax rate }\end{array}$} & \multirow[t]{2}{*}{$\begin{array}{l}\text { Share } \\
\text { college }\end{array}$} & \multicolumn{2}{|c|}{$\begin{array}{l}\text { Spending } \\
\$ 1,000 \text { per cap. }\end{array}$} & \multirow[t]{2}{*}{$\begin{array}{c}\text { Tax }+ \\
\text { sh. college }\end{array}$} \\
\hline & & & & Total & Police & \\
\hline $\begin{array}{l}\text { Panel A } \\
\text { Policy variable }\end{array}$ & --- & $\begin{array}{l}-0.065 \\
(0.015)\end{array}$ & $\begin{array}{c}0.428 \\
(0.202)\end{array}$ & $\begin{array}{l}-0.037 \\
(0.025)\end{array}$ & $\begin{array}{l}-0.621 \\
(0.196)\end{array}$ & --- \\
\hline $\begin{array}{l}\text { Panel B } \\
\ln (\text { med income })\end{array}$ & $\begin{array}{c}0.260 \\
(0.061)\end{array}$ & $\begin{array}{c}0.181 \\
(0.094)\end{array}$ & $\begin{array}{c}0.232 \\
(0.057)\end{array}$ & $\begin{array}{c}0.292 \\
(0.062)\end{array}$ & $\begin{array}{c}0.221 \\
(0.072)\end{array}$ & $\begin{array}{c}0.127 \\
(0.107)\end{array}$ \\
\hline Policy variable & --- & $\begin{array}{l}-0.028 \\
(0.022) \\
\end{array}$ & $\begin{array}{r}0.113 \\
(0.161) \\
\end{array}$ & $\begin{array}{c}0.024 \\
(0.017) \\
\end{array}$ & $\begin{array}{l}-0.167 \\
(0.239) \\
\end{array}$ & --- \\
\hline
\end{tabular}

Notes: Cells contain coefficients and standard errors from cross-sectional regressions of housing prices on jurisdiction-level income measures (equation 1). Standard errors are clustered by border area. The sample includes the 61 borders with information on all local policy variables in $1970(\mathrm{~N}=1,631)$. In the first column, median income is the only jurisdiction-level regressor. The remaining columns adds local policy variables. Sources for the local policy measures are reported in Appendix Table 1. See the notes to Tables 2 and 3 for more details on the sample and the specification. 


\section{Appendix Table 1: Sources for jurisdiction-level public goods data}

\begin{tabular}{l|l}
\hline Variable & Source \\
\hline $\begin{array}{l}\text { Current (non-educational) expenditure } \\
\bullet \quad \begin{array}{l}\text { Categories: Fire, parks, police, roads, } \\
\text { sanitation, sewers, other }\end{array}\end{array}$ & Census of Governments, 1972 \\
$\begin{array}{l}\text { Educational expenditure, per pupil } \\
\text { - Categories: Instructional, administrative }\end{array}$ & $\begin{array}{l}\text { Elementary and Secondary General } \\
\text { Information System (ELSEGIS), 1968-69 }\end{array}$ \\
$\begin{array}{ll}\text { Effective property tax rates }{ }^{3} \\
\text { Share residents with college degree }\end{array}$ & $\begin{array}{l}\text { Census of Governments, } 1972 \\
\text { Census of Population, 1970 }\end{array}$ \\
\hline
\end{tabular}

1: Non-educational expenditures are measured at the municipal level. In some states, counties are responsible for providing public services. Most jurisdiction pairs in the sample belong to the same county.

2: Educational spending per pupil is collected both from independent school districts and municipal school systems.

3: The Census of Government estimates effective property rates at the town level from samples of recent home sales. The effective property tax rate of a housing unit is the ratio of the property tax bill to the transaction price. These rates are reported for the $25^{\text {th }}, 50^{\text {th }}$ and $75^{\text {th }}$ percentile of the market value distribution. I assign units on the poor (wealthy) side of borders the effective rate for homes at the $75^{\text {th }}\left(25^{\text {th }}\right)$ percentile of the value distribution in their jurisdiction. That is, I assume that the houses on the border are larger than the typical city unit and smaller than the typical suburban unit. Exact data on property tax rates are available for 38 city-suburban borders. For 27 additional borders, I assign the suburb the property tax rate reported for the "balance of the metropolitan area" (that is, for all home sales in the suburban ring). In the remaining 37 cases, there is no information on property tax rates for any towns on the suburban side of the border. 
Appendix Table 2: Summary statistics, Jurisdiction variables

\begin{tabular}{|c|c|c|c|}
\hline & \multicolumn{2}{|c|}{1970} & $1970-80$ \\
\hline $\begin{array}{l}\text { Mean } \\
\text { (S.D.) }\end{array}$ & All jurisdictions & $\begin{array}{c}\text { Difference } \\
\text { across borders }\end{array}$ & $\begin{array}{l}\text { Change in } \\
\text { cross-border } \\
\text { difference } \\
\text { over time }\end{array}$ \\
\hline $\begin{array}{l}\text { Median family income } \\
(\$ 2000)\end{array}$ & $\begin{array}{l}\$ 49,980 \\
(\$ 10,227)\end{array}$ & $\begin{array}{c}\$ 9,926 \\
(\$ 8,918)\end{array}$ & $\begin{array}{c}\$ 2,880 \\
(\$ 2,181)\end{array}$ \\
\hline Poverty rate & $\begin{array}{c}0.067 \\
(0.036)\end{array}$ & $\begin{array}{c}0.046 \\
(0.031)\end{array}$ & $\begin{array}{c}0.026 \\
(0.025)\end{array}$ \\
\hline Share black & $\begin{array}{c}0.086 \\
(0.142)\end{array}$ & $\begin{array}{c}0.151 \\
(0.145)\end{array}$ & $\begin{array}{c}0.055 \\
(0.068)\end{array}$ \\
\hline Share college graduate & $\begin{array}{c}0.123 \\
(0.081)\end{array}$ & $\begin{array}{c}0.068 \\
(0.071)\end{array}$ & $\begin{array}{c}0.027 \\
(0.030)\end{array}$ \\
\hline $\begin{array}{l}\text { Property tax rate, } \% \text { of } \\
\text { sale price }\end{array}$ & $\begin{array}{c}2.535 \\
(1.115)\end{array}$ & $\begin{array}{c}0.723 \\
(0.482)\end{array}$ & \\
\hline $\begin{array}{l}\text { In } \$ 1,000 \text { ( } \$ 2000) \text { : } \\
\text { Instruction } \$ \text { per pupil }\end{array}$ & $\begin{array}{c}3.001 \\
(0.652)\end{array}$ & $\begin{array}{c}0.512 \\
(0.473)\end{array}$ & \\
\hline Non-education \$ per capita & $\begin{array}{c}0.736 \\
(0.424)\end{array}$ & $\begin{array}{c}0.493 \\
(0.431)\end{array}$ & \\
\hline Police \$ per capita & $\begin{array}{c}0.114 \\
(0.053)\end{array}$ & $\begin{array}{c}0.066 \\
(0.045)\end{array}$ & \\
\hline
\end{tabular}

Notes: Demographic and socio-economic variables are available for 102 city-suburban borders. Expenditure variables are available for 97 borders and property tax rates for 65 borders. 


\section{Appendix Table 3: Summary statistics, Block-level variables}

\begin{tabular}{l|ccc}
\hline & 1960 & 1970 & 1980 \\
\hline Average value, owned & $\$ 101,681$ & $\$ 102,651$ & $\$ 157,690$ \\
& $(53,358)$ & $(41,524)$ & $(91,863)$ \\
Number units & 42.689 & 39.347 & 41.954 \\
& $(43.783)$ & $(39.122)$ & $(58.118)$ \\
Mean \# rooms, owned & 5.713 & 5.736 & 5.478 \\
& $(0.933)$ & $(1.083)$ & $(1.022)$ \\
Share single family & 0.735 & 0.796 & 0.839 \\
& $(0.227)$ & $(0.265)$ & $(0.229)$ \\
Share black on block & 0.027 & 0.064 & 0.124 \\
& $(0.112)$ & $(0.201)$ & $(0.287)$ \\
Average contract rent & $\$ 457.90$ & $\$ 519.13$ & $\$ 575.80$ \\
& $(143.23)$ & $(169.23)$ & $(183.77)$ \\
\hline
\end{tabular}

Notes: Cells contain means and standard deviations of block-level variables. Means are reported for the sub-sample of blocks that have at least five owner-occupied units and that are not missing information on housing values. The one exception is average contract rent, which is reported for the sub-sample of blocks with at least five rental units. 